\title{
PENGARUH EDUKASI TERHADAP TINGKAT KECEMASAN PADA IBU DALAM MENGHADAPI MENOPAUSE DI KELURAHAN ORO-ORO DOWO KOTA MALANG
}

\author{
Devi Ertha Widorini ${ }^{1)}$, Surachmindari ${ }^{2)}$, Reni Wahyu Triningsih ${ }^{3)}$ \\ 1),2),3)Poltekkes Kemenkes Malang \\ Jalan Besar Ijen 77 C, Malang 65145, Jawa Timur \\ e-mail: devierthawidorini@gmail.com
}

\begin{abstract}
Menopause is a condition in a woman who has decreased ovarian function resulting in decreased estrogen hormone production so that menstruation stops for good. At menopause women will experience physical or psychological changes. Some mothers believe the myths that develop in the midst of life related to menopause. Therefore, it is expected that menopausal mothers have sufficient knowledge about the life cycle that will be experienced. With sufficient knowledge, then the anxiety in the mother of menopause will be reduced. Knowledge can be obtained through health education in the form of counseling. The purpose of this study was to determine the effect of counseling about menopause on the level of anxiety in menopausal women in the face of menopause. Preexperimental research design with One Group Pre-post Test Design and using cohort approach. This study used a simple random sampling technique with a sample of 31 menopausal women who met the inclusion criteria. The research instrument using HARS scale consists of 14 closed questions that have been modified. Then the data is analyzed with Wilcoxon Signed Rank Test. The results showed that the significance value of 0,000 $<\alpha(0.05)$. Because the significance value $<\alpha(0.05)$, then $H_{0}$ rejected, which means there is influence of counseling about menopause to the anxiety level in menopausal mothers in the face of menopause.
\end{abstract}

\section{Keywords : Counseling about Menopause, Level of Anxiety.}

\section{PENDAHULUAN}

Menopause adalah keadaan pada seseorang perempuan yang mengalami penurunan fungsi indung telur yang berakibat menurunnya produski hormon estrogen. Keadaan ini antara lain akan mengakibatkan terhentinya haid untuk selamanya. Usia perempuan yang memasuki masa menopause berkisar antara 45-55 tahun (Syafrudin, dkk, 2011). Pada masa menopause wanita akan mengalami perubahan-perubahan, baik perubahan pada fisik dan psikis. Perubahan yang dirasakan oleh wanita tersebut antara lain: perubahan pola menstruasi, rasa panas (hot flush), susah tidur, keluar keringat di malam hari, kerutan pada vagina, sembelit, penurunan libido, perubahan berat badan, perubahan kulit, perubahan pada mulut, fatigue, gejala gangguan motorik, sistem perkemihan dan sistem somatik, serta perubahan psikis seperti depresi, penurunan daya ingat, mudah tersinggung, gangguan psikis dan emosi (Mulyani, 2013).

Akan tetapi, sebagian wanita mempercayai mitos-mitos yang berkembang di tengah-tengah kehidupannya yang berkaitan dengan menopause. Banyak wanita yang menghadapi masa menopause terpengaruh dengan mitos-mitos seperti: mengalami menopause membuat produktivitas seorang wanita menurun, merasa tidak ada daya tarik lagi dimata pasangan, merupakan akhir hasrat seksual normal, tidak bergairah terhadap seks dan tidak akan bisa mencapai kepuasan seksual. Mitos-mitos ini dapat 
menimbulkan banyak ketakutan dan kecemasan pada ibu menopause karena tidak merasa percaya diri lagi, kurang menarik dan ketakutan jika pasangannya mencari pasangan yang lebih muda darinya (Mulyani, 2013).

Berdasarkan penelitian yang dilakukan oleh Ari Kusworo (2011) di Bantul tentang Pengaruh Pendidikan Kesehatan tentang Menopause terhadap Tingkat Kecemasan Ibu Usia 40-50 Tahun dalam Menghadapi Menopause di RT 08 Pedukuhan IX Ngestiharjo Kasihan Bantul didapatkan bahwa tingkat kecemasan ibu usia 40-50 tahun sebelum diberikan pendidikan kesehatan tentang menopause, yaitu mayoritas mempunyai kecemasan sedang dan kecemasan berat yaitu sebanyak 16 orang atau 45,7\% sedangkan nilai terendah terdapat tingkat kecemasan ringan yaitu sebanyak 3 orang $(8,6 \%)$. Kemudian setelah diberikan pendidikan kesehatan tentang menopause, hasil tingkat kecemasan yang tertinggi yaitu tingkat kecemasan ringan yaitu sebanyak 29 orang atau $82,9 \%$ dan hasil tingkat kecemasan yang terendah yaitu kecemasan sedang sebanyak 6 orang $(17,1 \%)$ (Kusworo, 2011). Sehingga dapat disimpulkan bahwa ada pengaruh pendidikan kesehatan tentang menopause terhadap tingkat kecemasan ibu usia 4050 tahun dalam menghadapi menopause di RT 08 Pedukuhan IX Ngestiharjo Kasihan Bantul

Sedangkan berdasarkan studi pendahuluan yang dilakukan peneliti, di RW 03 dan RW 04 Kelurahan Oro-Oro Dowo Kota Malang pada bulan April 2017, terdapat $39 \mathrm{ibu}$ menopause dengan lama menopause 1-2 tahun. Dari 5 responden yang diberikan kuesioner (skala HARS), maka 2 responden $(40 \%)$ mengalami kecemasan ringan, 2 responden (40\%) mengalami kecemasan sedang dan 1 responden (20\%) mengalami kecemasan berat. Dari 5 responden tersebut mengatakan belum pernah mendapatkan pengetahuan tentang menopause dan belum mengetahui cara mengatasi masalah yang berkaitan dengan perubahan-perubahan yang dialami ibu selama masa menopause.

Oleh sebab itu, diharapkan wanita menopause memiliki pengetahuan yang cukup tentang siklus kehidupan yang akan dialaminya. Dengan pengetahuan yang cukup, maka kecemasan pada ibu menopause akan berkurang. Hal ini merupakan tugas seorang bidan dalam memberikan pengetahuan. Salah satunya adalah dengan kegiatan penyuluhan. Penyuluhan tentang menopause ini bertujuan untuk membantu ibu menopause dalam mengatasi masalah yang berkaitan dengan perubahanperubahan yang terjadi saat menopause, sehingga ibu mampu beradaptasi dengan tanda dan gejala yang muncul dalam dirinya, meningkatkan keyakinan serta mengurangi rasa cemas pada saat menghadapi menopause. Dengan begitu mereka akan berpikir positif dan menerima bahwa perubahan-perubahan yang terjadi selama menopause adalah hal yang wajar terjadi dan merupakan proses yang alamiah sehingga mereka dapat menjalani masa menopause dengan tenang dan tanpa rasa takut.

Berdasarkan uraian yang telah dikemukakan di atas, maka peneliti tertarik untuk melakukan penelitian dengan judul "Pengaruh Penyuluhan tentang Menopause terhadap Tingkat Kecemasan pada Ibu Menopause dalam Menghadapi Menopause di Kelurahan Oro-Oro Dowo Kota Malang."

\section{METODE PENELITIAN}

Desain penelitian yang digunakan dalam penelitian ini adalah praeksperimen dengan rancangan One Group Pra-post Test Design dan menggunakan pendekatan cohort. Maka penelitian ini bermaksud untuk menggali ada tidaknya pengaruh penyuluhan tentang menopause terhadap tingkat kecemasan pada ibu menopause dalam menghadapi menopause. 
Populasi dalam penelitian ini adalah semua ibu menopause dengan lama menopause 1-2 tahun di RW 03 dan RW 04 Kelurahan Oro-Oro Dowo Kota Malang pada periode Juni 2017, yaitu sejumlah 34 orang. Sampel dalam penelitian ini adalah sebagian ibu menopause dengan lama menopause 1-2 tahun di RW 03 dan RW 04 Kelurahan Oro-Oro Dowo Kota Malang pada periode Juni 2017 yang memenuhi kriteria inklusi. Besar sampel dalam penelitian ini dihitung dengan menggunakan rumus Slovin dengan tingkat kesalahan 5\%, yaitu sejumlah 31 orang.Teknik sampling yang digunakan pada penelitian ini adalah simple random sampling. Penelitian ini mengambil sebagian sampel yang dapat mewakili karakteristik populasi secara acak dengan kesempatan yang sama pada ibu menopause dengan lama menopause 1-2 tahun, yaitu RW 03 dan RW 04 Kelurahan Oro-Oro Dowo Kota Malang. Alat pengumpulan data atau instrumen data yang digunakan dalam penelitian ini adalah kuesioner yang menggunakan skala HARS dengan 14 pertanyaan dan dimodifikasi sesuai dengan timbulnya perubahan, tanda dan gejala yang dapat menyebabkan kecemasan pada ibu menopause. Bentuk dari jenis pertanyaan dalam penelitian ini menggunakan pertanyaan tertutup, yaitu mengharapkan responden memilih salah satu atau beberapa alternatif jawaban dari setiap pertanyaan yang telah disediakan sesuai dengan apa yang dirasakan respond

Ada tidaknya pengaruh penyuluhan tentang menopause terhadap tingkat kecemasan pada ibu menopause dalam menghadapi menopause dan mengingat penelitian ini bertujuan untuk mengukur dua variabel dimana variabel independen berskala nominal dan variabel dependen berskala ordinal maka uji statistik yang digunakan adalah Wilcoxon Signed Rank Test sesuai dengan sebaran data yang didapatkan dari hasil penelitian dengan taraf signifikansi yang digunakan $\alpha=$
0,05 . Kriteria pengambilan keputusan adalah sebagai berikut:

1. $\mathrm{H}_{0}$ ditolak jika nilai signifikansi $<0,05$ yang berarti ada pengaruh penyuluhan tentang menopause terhadap tingkat kecemasan pada ibu menopause dalam menghadapi menopause di Kelurahan Oro-Oro Dowo Kota Malang.

2. $\mathrm{H}_{0}$ diterima jika nilai signifikansi > 0,05 yang berarti tidak ada pengaruh penyuluhan tentang menopause terhadap tingkat kecemasan pada ibu menopause dalam menghadapi menopause di Kelurahan Oro-Oro Dowo Kota Malang.

\section{HASIL PENELITIAN}

\section{Data Umum}

a. Karakteristik Berdasarkan Usia Menopause

Karakteristik

Responden berdasarkan usia menopause di Kelurahan Oro-Oro Dowo Kota Malang seluruh responden sejumlah 31 orang $(100 \%)$ berusia 46-55 tahun.

b. Karakteristik Responden Berdasarkan Pendidikan Tabel 4.1 Distribusi Frekuensi Karakteristik Responden Berdasarkan Pendidikan di Kelurahan Oro-Oro Dowo Kota Malang Tahun 2017

\begin{tabular}{ccc}
\hline Pendidikan & $\begin{array}{c}\text { Frekuensi } \\
\text { (f) }\end{array}$ & $\begin{array}{c}\text { Presentase } \\
(\mathbf{\%})\end{array}$ \\
\hline SD & 4 & 12,9 \\
SMP & 7 & 22,6 \\
SMA & 19 & 61,3 \\
Perguruan & 1 & 3,2 \\
Tinggi & \multicolumn{3}{c}{$\mathbf{1 0 0}$} \\
\hline Jumlah & $\mathbf{3 1}$ & 4.1 \\
\multicolumn{4}{c}{ Berdasarkan tabel $\quad$ rata-rata } \\
menunjukkan bahwa randikan \\
responden berdasarkan pendidikan \\
sebagian besar adalah SMA, yaitu \\
sejumlah 19 orang (61,3\%).
\end{tabular}


c. Karakteristik

Responden

Berdasarkan Pekerjaan

Tabel 4.2 Distribusi

Frekuensi Karakteristik Responden

Berdasarkan Pekerjaan di

Kelurahan Oro-Oro Dowo Kota

Malang Tahun 2017

\begin{tabular}{ccc}
\hline Pekerjaan & $\begin{array}{c}\text { Frekuensi } \\
(\mathbf{f})\end{array}$ & $\begin{array}{c}\text { Presentase } \\
(\mathbf{\%})\end{array}$ \\
\hline Wiraswasta & 10 & 32,3 \\
Swasta & 2 & 6,4 \\
IRT & 19 & 61,3 \\
\hline Jumlah & $\mathbf{3 1}$ & $\mathbf{1 0 0}$ \\
\hline Berdasarkan & tabel & 4.2
\end{tabular}

menunjukkan bahwa karakteristik responden berdasarkan pekerjaan sebagian besar adalah IRT, yaitu sejumlah 19 orang $(61,3 \%)$.

\section{Data Khusus}

Tabel 4.3 Distribusi Frekuensi Tingkat Kecemasan pada Ibu Menopause dalam Menghadapi Menopause Sebelum Penyuluhan (Pre Test) di Kelurahan Oro-Oro Dowo Kota Malang Tahun 2017

\begin{tabular}{|c|c|c|}
\hline \multirow{2}{*}{$\begin{array}{c}\text { Tingkat } \\
\text { Kecemasan }\end{array}$} & \multicolumn{2}{|c|}{$\begin{array}{l}\text { Sebelum Penyuluhan } \\
\text { (Pre Test) }\end{array}$} \\
\hline & $\mathbf{f}$ & $\%$ \\
\hline $\begin{array}{l}\text { Tidak Cemas } \\
(\text { Skor }<6)\end{array}$ & 3 & 9,7 \\
\hline $\begin{array}{l}\text { Kecemasan } \\
\text { Ringan (Skor } \\
\text { 6-14) }\end{array}$ & 18 & 58,1 \\
\hline $\begin{array}{l}\text { Kecemasan } \\
\text { Sedang (Skor } \\
15-27 \text { ) }\end{array}$ & 8 & 25,8 \\
\hline $\begin{array}{l}\text { Kecemasan } \\
\text { Berat (Skor > } \\
\text { 27) }\end{array}$ & 2 & 6,4 \\
\hline Jumlah & 31 & 100 \\
\hline
\end{tabular}

Berdasarkan tabel 4.3 menunjukkan bahwa sebagian besar tingkat kecemasan sebelum penyuluhan (pre test) adalah kecemasan ringan, yaitu sejumlah 18 orang $(58,1 \%)$.

Tabel 4.4 Distribusi Frekuensi Tingkat Kecemasan pada Ibu Menopause dalam Menghadapi Menopause Setelah
Penyuluhan (Post Test) di Kelurahan Oro-Oro Dowo Kota Malang Tahun 2017

\begin{tabular}{|c|c|c|}
\hline \multirow{2}{*}{$\begin{array}{c}\text { Tingkat } \\
\text { Kecemasan }\end{array}$} & \multicolumn{2}{|c|}{$\begin{array}{c}\text { Setelah Penyuluhan (Post } \\
\text { Test) }\end{array}$} \\
\hline & $\mathbf{f}$ & $\%$ \\
\hline $\begin{array}{l}\text { Tidak Cemas } \\
(\text { Skor }<6)\end{array}$ & 18 & 58,1 \\
\hline $\begin{array}{l}\text { Kecemasan } \\
\text { Ringan (Skor 6- } \\
\text { 14) }\end{array}$ & 10 & 32,2 \\
\hline $\begin{array}{l}\text { Kecemasan } \\
\text { Sedang } \quad \text { (Skor } \\
15-27)\end{array}$ & 3 & 9,7 \\
\hline $\begin{array}{l}\text { Kecemasan } \\
\text { Berat (Skor > } \\
27 \text { ) }\end{array}$ & 0 & 0 \\
\hline Jumlah & 31 & 100.0 \\
\hline
\end{tabular}

Berdasarkan tabel 4.4 menunjukkan bahwa sebagian besar tingkat kecemasan setelah penyuluhan (post test) adalah tidak cemas, yaitu sejumlah 18 orang $(58,1 \%)$.

\section{Hasil Uji Statistik}

Tabel 4.5 Hasil Uji Statistik

Wilcoxon Signed Rank Test

$$
\text { Test Statistics }{ }^{b}
$$

\begin{tabular}{|l|r|}
\hline & $\begin{array}{c}\text { kecemasan (post) - } \\
\text { kecemasan (pre) }\end{array}$ \\
\hline$Z$ & -4.523 \\
Asymp. Sig. (2-tailed) & .000 \\
\hline
\end{tabular}

a. Based on positive ranks.

b. Wilcoxon Signed Ranks Test

Berdasarkan tabel

menunjukkan bahwa nilai signifikansi sebesar 0,000 dengan nilai $\alpha=0,05$. Dari hasil tersebut ditemukan bahwa nilai signifikansi $0,000<\alpha(0,05)$. Karena nilai signifikansi $<\alpha$, maka $\mathrm{H}_{0}$ ditolak, yang artinya ada pengaruh penyuluhan tentang menopause terhadap tingkat kecemasan pada ibu menopause dalam menghadapi menopause.

\section{PEMBAHASAN}

Berdasarkan hasil penelitian, dapat diketahui tingkat kecemasan ibu dalam menghadapi menopause sebelum diberikan penyuluhan 
menunjukkan bahwa sebagian besar ibu berada dalam kecemasan ringan, yaitu sejumlah 18 orang $(58,1 \%)$, tidak cemas sejumlah 3 orang $(9,7 \%)$, kecemasan sedang sejumlah 8 orang $(25,8 \%)$ dan kecemasan berat sejumlah 2 orang $(6,4 \%)$. Hal ini dimungkinkan karena adanya beberapa faktor yang mempengaruhi keragaman dan perbedaan tingkat kecemasan ibu dalam menghadapi menopause. Hal tersebut sesuai dengan pendapat Aprilia dan Nunik (2007), tingkat kecemasan ibu dalam menghadapi menopause dipengaruhi oleh usia, pengetahuan, sikap, dukungan keluarga dan tingkat pendidikan.

Berdasarkan karakteristik usia menopause responden di Kelurahan Oro-Oro Dowo Kota Malang seluruh responden sejumlah 31 orang $(100 \%)$ berusia 46-55 tahun. Hal ini sesuai dengan teori bahwa menopause adalah suatu keadaan pada seseorang perempuan yang mengalami penurunan fungsi indung telur yang berakibat menurunnya produksi hormon estrogen dan terhentinya haid untuk selamanya. Usia perempuan yang memasuki masa menopause berkisar antara 45-55 tahun (Syafrudin, dkk. 2011). Pada wanita dengan rentang usia 45-55 akan mengalami suatu gejala dan keluhan menopause seingga akan timbul kecemasan akibat perubahan yang terjadi pada tubuh. Seperti yang disebutkan dalam kuesioner yang mengukur tingkat kecemasan pada ibu menopause, yaitu ketegangan, ketakutan, gangguan tidur, gangguan kecerdasan, perasaan depresi, gejala somatik (otot-otot), gejala sensorik, gejala kardiovaskular, gejala pernapasan, gejala gastrointestinal, gejala urogenetalia dan gejala vegetatif/ otonom.

Selain itu pada karakteristik menunjukkan bahwa responden berdasarkan pendidikan sebagian besar adalah SMA, yaitu sejumlah 19 orang $(61,3 \%)$. Hal tersebut sesuai dengan teori bahwa semakin banyak pengetahuan yang dimiliki semakin mudah proses penerimaan informasi. Sehingga kecemasan menjelang menopause dapat diatasi dengan baik (Aprilia dan Nunik, 2007). Namun, menurut Notoatmodjo (2010) menyatakan bahwa bukan berarti seseorang yang berpendidikan rendah pasti berpengetahuan rendah pula. Karena peningkatan pengetahuan seseorang tidak mutlak diperoleh di pendidikan formal tetapi juga bisa diperoleh dari sumber informasi lain. Oleh sebab itu, setiap wanita yang akan memasuki menopause harus memiliki pengetahuan yang memadai tentang menopause agar dapat menjalani masa tersebut dengan lebih tenang sehingga wanita tidak mengalami kecemasan (Aprilia dan Nunik, 2007).

Di lihat karakteristik responden berdasarkan pekerjaan sebagian besar adalah IRT, yaitu sejumlah 19 orang $(61,3 \%)$. Apabila seorang wanita tidak memiliki kesibukan diluar rumah contohnya ibu rumah tangga, maka seseorang akan mudah cemas dalam menghadapi sesuatu. Hal ini didukung oleh teori bahwa ketika tidak ada kesibukan, pikiran seseorang menjadi hampa atau kosong sehingga kecemasan, ketakutan, kebencian dan lain-lain dengan mudah memasuki pikiran seseorang. Kecemasan tidak akan muncul ketika sedang aktif dalam kegiatan (Carniege, 2007). Hal tersebut juga didukung oleh Darmojo dan Hadi (2006), mengatakan bahwa seorang wanita yang mempunyai aktivitas sosial di luar rumah akan lebih banyak mendapat informasi baik misalnya dari teman bekerja atau teman dalam aktivitas sosial.

Berdasarkan penelitian, dapat diketahui tingkat kecemasan ibu dalam menghadapi menopause sebelum 
penyuluhan menunjukkan bahwa sebagian besar tingkat kecemasan setelah penyuluhan (post test) adalah tidak cemas, yaitu sejumlah 18 orang $(58,1 \%)$, kecemasan ringan sejumlah 10 orang $(32,2 \%)$ dan kecemasan sedang sejumlah 3 orang $(9,7 \%)$. Perubahan tingkat kecemasan dalam menghadapi menopause meskipun sudah dilakukan penyuluhan tentang menopause disebabkan karena dari faktor sikap individu itu sendiri. Hal ini sesuai dengan teori bahwa sikap yang ditunjukkan dalam menjalani masa menopause sebagai bagian dari kehidupan normal setiap wanita juga berpengaruh dalam mengurangi atau mengatasi kecemasan yang dialaminya. Setiap individu yang memandang suatu permasalahan dari sisi positif maka akan memberikan pengaruh positif kepada dirinya dan individu yang memandang suatu permasalahan dari sisi negatif maka akan memberikan pengaruh yang negatif pula kepada dirinya yang nantinya hal ini akan mempengaruhi tindakannya (Aprilia dan Nunik, 2007).

Hasil penelitian juga menunjukkan bahwa setelah dilakukan penyuluhan tentang menopause ada 18 orang $(58,1 \%)$ tidak mengalami kecemasan. Hal ini disebabkan ibu telah mengetahui bahwa menopause merupakan peristiwa alamiah dan konsekuensi dari proses penuaan, menurunnya fungsi organ bahkan berhentinya produksi hormon estrogen. Sehingga ibu menopause harus menghadapinya dengan penuh keikhlasan dan selalu berpikir positif serta siap menghadapi gejolak-gejolak psikologis akibat menopause. Pernyataan tersebut didukung oleh Mulyani (2013) yang menyatakan bahwa masa setelah menopause yaitu ketika seseorang wanita telah mampu menyesuaikan dengan kondisinya, sehingga tidak mengalami gangguan fisik yang berlangsung kurang lebih 35 tahun setelah menopause. Pada masa ini tercapai suatu keadaan keseimbangan hormonal yang baru, sehingga tidak ada lagi gangguan vegetatif maupun psikis.

Berdasarkan hasil penelitian dapat diketahui perubahan tingkat kecemasan ibu menopause dalam menghadapi menopause sebelum dan sesudah penyuluhan. Setelah penyuluhan, sebagian besar responden yang tidak cemas sejumlah 3 orang $(9,7 \%)$ menjadi 18 orang $(58,1 \%)$, responden dengan kecemasan ringan sejumlah 18 orang $(58,1 \%)$ menjadi 10 orang $(32,2 \%)$, responden dengan kecemasan sedang sejumlah 8 orang $(25,8 \%)$ menjadi 3 orang $(9,7 \%)$ dan responden dengan kecemasan berat sejumlah 2 orang $(6,4 \%)$ menjadi 0 .

Hasil analisa dengan uji Wilcoxon Signed Rank Test diketahui bahwa nilai signifikansi $0,000<\alpha(0,05)$. Karena nilai signifikansi $<\alpha$, maka $\mathrm{H}_{0}$ ditolak, yang artinya ada pengaruh penyuluhan tentang menopause terhadap tingkat kecemasan pada ibu menopause dalam menghadapi menopause.

Tingkat kecemasan pada ibu menopause yang menunjukkan bahwa rata-rata tingkat kecemasan sebelum penyuluhan adalah 13,03, setelah penyuluhan maka rata-rata tingkat kecemasan responden pada post test 3 hari setelah penyuluhan menjadi 7,32. Sehingga dapat disimpulkan bahwa terjadi penurunan tingkat kecemasan pada ibu menopause.

Peneliti berpendapat bahwa pendidikan kesehatan melalui metode penyuluhan berpengaruh terhadap tingkat kecemasan karena kecemasan tidak akan muncul apabila pengetahuan yang dimiliki cukup. Pendidikan kesehatan melalui penyuluhan ini merupakan suatu proses yang bertujuan untuk mempengaruhi pengetahuan, sikap dan 
perilaku yang ada hubungannya dengan kesehatan perorangan ataupun kelompok. Hal ini dibuktikan dengan penelitian yang telah dilakukan oleh peneliti, yaitu ibu dengan lama menopause 1-2 tahun yang memiliki penurunan tingkat kecemasan berat dan sedang menjadi kecemasan ringan hingga ibu tidak mengalami cemas. Selain itu, didukung oleh teori menurut Azril Azwar dalam Nugroho dan Ari (2010), mengatakan bahwa penyuluhan adalah kegiatan pendidikan yang dilakukan dengan cara menyebarkan pesan, menanamkan keyakinan sehingga masyarakat tidak saja sadar, tahu, dan mengerti, tetapi juga mau dan bisa melakukan suatu anjuran yang ada hubungan dengan kesehatan.

Sehingga dapat disimpulkan bahwa penyuluhan berpengaruh terhadap tingkat kecemasan pada ibu menopause dalam menghadapi menopause. Pernyataan tersebut didukung oleh teori bahwa dalam beberapa kasus kecemasan, pemberian penyuluhan merupakan pilihan utama. Penyuluhan seringkali diartikan sebagai pemberian informasi dari orang yang mengetahui dan memahami untuk membantu orang yang diberi penyuluhan dalam pengambilan keputusan yang tepat (Ningrum, 2013).

\section{PENUTUP}

1. Hasil penelitian menunjukkan sebagian besar tingkat kecemasan sebelum penyuluhan (pre test) adalah kecemasan ringan, yaitu sejumlah 18 orang $(58,1 \%)$, tidak cemas sejumlah 3 orang $(9,7 \%)$, kecemasan sedang sejumlah 8 orang $(25,8 \%)$ dan kecemasan berat sejumlah 2 orang $(6,4 \%)$.

2. Hasil Penelitian Sebagian besar tingkat kecemasan setelah penyuluhan (post test) adalah tidak cemas, yaitu sejumlah 18 orang $(58,1 \%)$, kecemasan ringan sejumlah 10 orang $(32,2 \%)$ dan kecemasan sedang sejumlah 3 orang $(9,7 \%)$.

3. Hasil Uji Statistik Berdasarkan hasil uji Wilcoxon Signed Rank Test menunjukkan bahwa nilai signifikansi $0,000<\alpha(0,05)$. Oleh karena nilai signifikansi $<\alpha(0,05)$, maka $\mathrm{H}_{0}$ ditolak, yang artinya ada pengaruh penyuluhan tentang menopause terhadap tingkat kecemasan pada ibu menopause dalam menghadapi menopause. perubahan-perubahan yang sedang dialami.

\section{DAFTAR PUSTAKA}

Ali, Z. 2010. Dasar-dasar Pendidikan Kesehatan Masyarakat dan Promosi Kesehatan. Jakarta: Trans Info Media.

Aprilia dan Nunik. 2007. Faktor yang Mempengaruhi Tingkat

Kecemasan pada Wanita Perimenopause. Surabaya: Jurnal Universitas Airlangga.

Carnegie, Dale. 2007. Mengatasi Rasa Cemas dan Depresi. Yogyakarta: Think.

Dalami, Ermawati, dkk. 2009. Asuhan Keperawatan Jiwa dengan Masalah Psikososial. Jakarta: Trans Info Media.

Darmojo, R. Boedhi dan Hadi Martono. 2006. Buku Ajar Geriatri: Ilmu Kesehatan Usia Lanjut. Jakarta: Balai Penerbit FKUI.

Fitria, Nita, dkk. 2013. Laporan Pendahuluan tentang Masalah Psikososial. Jakarta: Salemba Medika.

Fitriani, Sinta. 2011. Promosi Kesehatan. Yogyakarta: Graha Ilmu.

Hidayat, A. Aziz Alimul. 2008. Metode Penelitian Keperawatan dan Teknik Analisis Data. Jakarta: Salemba Medika.

Kasdu, Dini. 2002. Kiat Sehat dan Bahagia di Usia Menopause. Jakarta: Puspa Swara. 
Kusworo, Ari. 2011. Pengaruh Pendidikan Kesehatan Tentang Menopause Terhadap Tingkat Kecemasan Ibu Usia 40-50 Tahun Dalam Menghadapi Menopause di RT 08 Pedukuhan IX Ngestiharjo Kasihan Bantul. Yogyakarta: Jurnal Univeristas 'Aisyiyah Yogyakarta.

Kumalasari dan Iwan. 2012. Kesehatan Reproduksi untuk Mahasiswa Kebidanan dan Keperawatan. Jakarta: Salemba Medika.

Mansur, Herawati. 2011. Psikologi Ibu dan Anak untuk Kebidanan. Jakarta: Salemba Medika.

Mubarak, W. I, dkk. 2007. Promosi Kesehatan Sebuah Pengamatan Proses Belajar Mengejar dalam Pendidikan. Yogyakarta: Graha Ilmu.

Mubarak dan Nurul. 2009. Ilmu Kesehatan Masyarakat Teori dan Aplikasi. Jakarta: Salemba Medika.

Mulyani, Nina Siti. 2013. Menopause Akhir Siklus Menstruasi pada Wanita di Usia Pertengahan. Yogyakarta: Nuha Medika.

Ningrum, Hesty Setya. 2013. Hubungan Pengetahuan Dengan Kecemasan Ibu Hamil Tentang Perubahan Fisiologis Kehamilan. Malang: Karya Tulis Ilmiah Poltekkes Kemenkes Malang.

Notoatmodjo, S. 2010. Promosi Kesehatan Teori dan Aplikasi Edisi Revisi. Jakarta: Rineka Cipta.

Notoatmodjo, S. 2012. Promosi Kesehatan dan Perilaku Kesehatan. Jakarta: Rineka Cipta.

Notoatmodjo, S. 2012. Metodologi Penelitian Kesehatan. Jakarta: Rineka Cipta.

Nugroho dan Ari. 2010. Kesehatan Wanita, Gender dan
Permasalahannya.

Yogyakarta: Nuha Medika.

Nursalam. 2009. Konsep dan Penerapan Metodologi Penelitian Ilmu Keperawatan (Pedoman Skripsi, Tesis, dan Instrumen Penelitian Keperawatan). Jakarta: Salemba Medika.

Pujipratiwi, A. P. R. 2013. Pengaruh Konseling Menopause terhadap Tingkat Kecemasan Menghadapi Menopause pada Wanita Usia 45-55 tahun. Malang: Karya Tulis Ilmiah Poltekkes Kemenkes Malang.

Sibagariang, Eva Ellya, dkk. 2010. Kesehatan Reproduksi Wanita. Jakarta: Trans Info Media.

Stuart, Gail W. 2013. Buku Saku Keperawatan Jiwa Edisi 5. Jakarta: EGC.

Sugiyono. 2015. Statistika untuk Penelitian. Bandung: Alfabeta.

Susilo, R. 2011. Pendidikan Kesehatan dalam Keperawatan. Yogyakarta: Nuha Medika.

Syafrudin, dkk. 2011. Himpunan Penyuluhan Kesehatan (pada Remaja, Keluarga, Lansia dan Masyarakat). Jakarta: Trans Info Media.

Yusuf, dkk. 2015. Buku Ajar Keperawatan Kesehatan Jiwa. Jakarta: Salemba Medika. 